Comunidades endémicas de Cactáceas en peligro de extinción. Una necesidad de conservación de los recursos naturales del distrito de Pacaycasa. Ayacucho-Perú

\title{
Endemic communities of Cactaceae in danger of extinction. A need for conservation of natural resources in the district of Pacaycasa. Ayacucho-Peru

\author{
Huamaní-Sulca Roxana Erika ${ }^{1}$ (D) De La Cruz-Arango Jesúis ${ }^{1 *(D)}$, Chuchón-Martinez Saúl², Pelaez-Pelaez Freddy ${ }^{3}$
}

\begin{tabular}{l} 
Data of the Article \\
\hline \\
\hline 'Botany Laboratory. \\
Academic Department of Biological Sciences. \\
Faculty of Biological Sciences. \\
National University of San Cristobal de Huamanga. \\
Av. Independencia s/n Ciudad Universitaria \\
"Los Módulos. \\
Ayacucho-Perú \\
sul.erih@gmail.com \\
'Environmental Microbiology Laboratory. \\
Academic Department of Biological Sciences. \\
Faculty of Biological Sciences. \\
National University of San Cristóbal de Huamanga. \\
Independence Avenue s/n University City \\
"Los Módulos". \\
Ayacucho - Peru. \\
saul.chuchon@unsch.edu.pe \\
'Faculty of Biological Sciences. \\
National University of Trujillo. \\
John Paul II Avenue s/n. \\
Trujillo - Perú. \\
Tel: +51(044)221321 \\
fpelaez@ @nitru.edu.pe \\
*Contact address: \\
Jesus De La Cruz Arango \\
Academic Department of Biological ciences \\
Faculty of Biological Sciences. \\
National University of San Cristobal de Huamanga. \\
Av. Independencia s/n Ciudad Universitaria. \\
"Los Módulos". \\
Ayacucho - Perú. \\
Phone 066401622 - 966002308. \\
Jesús De La Cruz Arango \\
E-mail: jesusunsch@ gmail.com \\
Palabras clave: \\
Cactáceas, \\
endémicas, \\
endemismo, \\
flora, \\
vegetación, \\
xerofítica, \\
biodiversidad, \\
Andes, \\
Ayacucho. \\
\hline
\end{tabular}

\section{J. Selva Andina Biosph.} 2020; 8(2):92-109.

ID of article: 094/JSAB/2020

\section{Record from the article.}

Received June, 2020.

Returned August,

Accepted September, 2020

Available online November 2020

\section{Resumen}

Se estudió comunidades endémicas de cactáceas en el cerro San Cristóbal. Relacionado a un grupo de plantas que tienen una serie de adaptaciones morfo-fisiológicas especiales y que juegan un rol importante en un ecosistema xerofítico donde la supervivencia es difícil. Se llevó a cabo durante el año 2013, entre altitudes de 2415 a $2750 \mathrm{msnm}$ con la finalidad de analizar su densidad, estructura, distribución y estado de conservación de las especies. Información valiosa para la toma de decisiones referente a estas áreas y especies por las instancias correspondientes. Siendo el muestreo utilizado aleatorio-estratificado, con 24 parcelas de 50 x $50 \mathrm{~m}$, establecidos en tres estratos: bajo (<2500 msnm), medio (2500 a $2600 \mathrm{msnm}$ ) y alto (> $2600 \mathrm{msnm})$. En cada una de las unidades muestrales se identificaron las especies usando claves taxonómicas, se evaluaron las características poblacionales, los cuales se procesaron y analizaron con la ayuda de herramientas informáticos Software $\mathrm{R}$ Versión 3.0.0 y Microsoft Excel 2013. Los resultados mostraron 5 especies endémicas: B. hertlingiana, E. peruviana, $C$. quadrangularis, $C$. ayacuchoensis y $O$. doelzianus, cuatro especies presentan densidades poblacionales bajas, O. doelzianus, C. ayacuchoensis, E. peruviana y C. quadrangularis con 16, 14, 9 y 8 plantas/ha, mientras que $B$. hertlingiana mayor densidad con 134 plantas/ha. Según estado de conservación, dos especies endémicas propias de la zona estudio $C$. ayacuchoensis y $C$. quadrangularis, se encuentran en categoría de peligro, con una densidad poblacional baja. Presentan un patrón de distribución amontonada y regeneración natural. Estas especies endémicas están en peligro por distintas amenazas como perturbación natural y antropogénica, principalmente por el crecimiento demográfico que genera tala y destrucción de ecosistemas para construcción de viviendas.

ㄷ 2020. Journal of the Selva Biosphere ${ }^{\circledR}$. Bolivia. Todos os direitos reservados.

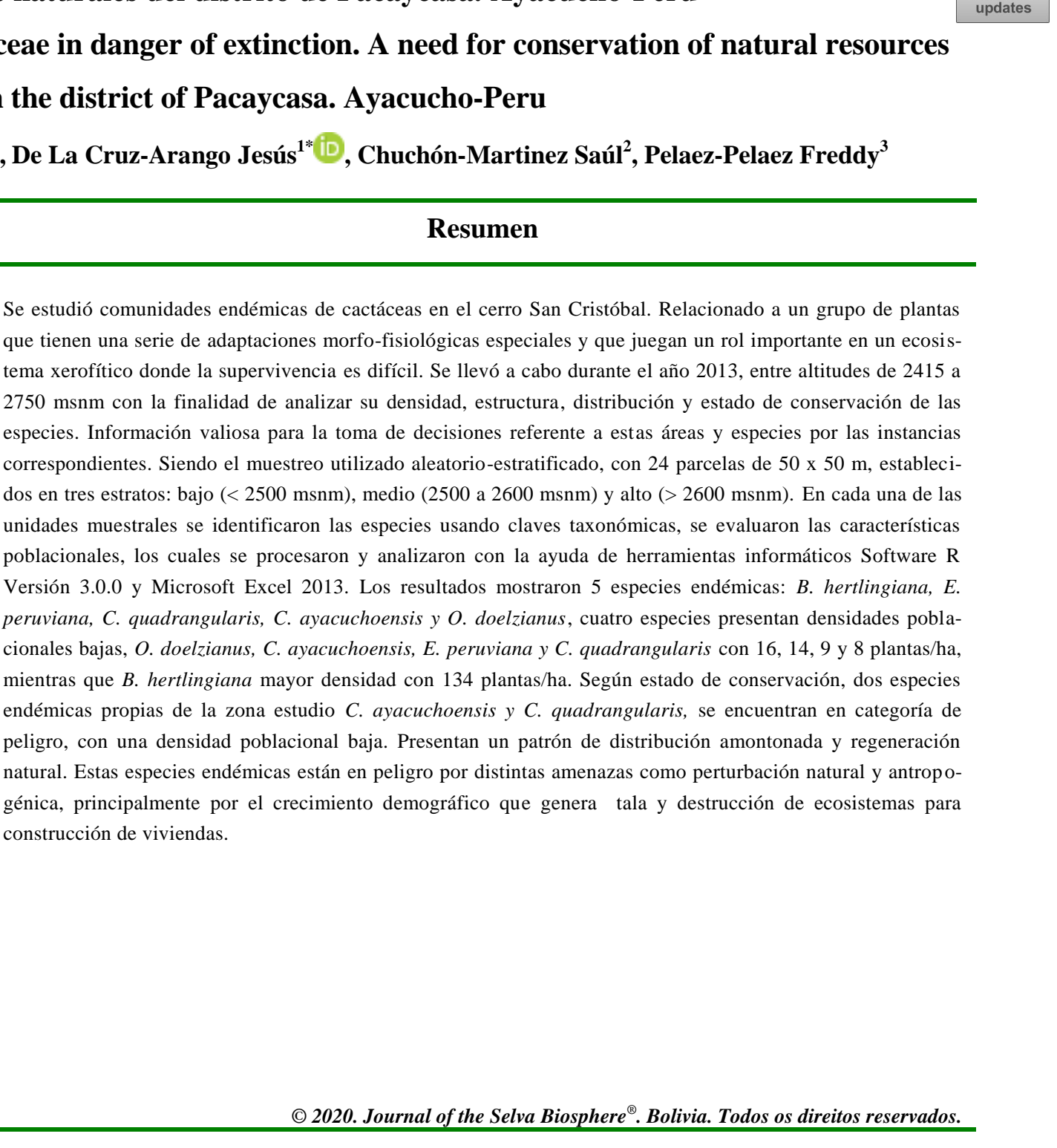

Abstract

Endemic cactus communities were studied in San Cristobal hill. It is related to a group of plants that have a series of special morpho-physiological adaptations and play an important role in a xerophytic ecosystem where survival is difficult. It was carried out during 2013, between altitudes of 2415 and 2750 meters above sea level with the purpose of analyzing its density, structure, and distribution, and conservation status of the species. Important information for decision making regarding these areas and species by the corresponding authorities. The sampling used is aleatory-stratified, with 24 plots of 50 x $50 \mathrm{~m}$, established in three strata: low (<2500 masl), medium (2500 to 2600 masl), and high (> 2600 masl). In each of the sample units, species were identified using taxonomic keys and population characteristics were evaluated, which were processed and analyzed with the help of computer tools Software R Version 3.0.0 and Microsoft Excel 2013. The results showed 5 endemic species: B. hertlingiana, E. peruviana, C. quadrangularis, C. ayacuchoensis and $O$. doelzianus, four species have low population densities, O. 
doelzianus, C. ayacuchoensis, E. peruviana and C. quadrangularis with $16,14,9$, and 8 plants/ha, while $B$. hertlin-

Editado por:

Selva Andina

Research Society

\section{Keywords:}

Cacti,

endemic,

endemism,

flora,

vegetation,

xerophytic,

biodiversity,

Andes,

Ayacucho. giana has a higher density with 134 plants/ha. According to the conservation status, two endemic species, $C$. ayacuchoensis and $C$. quadrangularis, are in the endangered category with a low population density. They present a pattern of crowded distribution and natural regeneration. However, these endemic species are endangered by different threats such as natural and anthropogenic disturbance, mainly because of the population growth that generates logging and destruction of ecosystems for housing construction

\section{Introduction}

San Cristobal Hill is a xerophytic ecosystem, it is part of the valley ravines of the community of Compañía, district of Pacaycasa. This ecosystem is very important because it is home to communities of cactus with the presence of endemic species, where the biodiversity of arid zones such as microorganisms, flora and fauna in general interact. It presents low precipitations during the year, dry alluvial causes, erosion soils as a result of annual rains. Dominant xerophytic vegetation, with special anatomical and physiological morph adaptations, to resist the extreme conditions of the environment. Cactaceae are the dominant and richest plants in this ecosystem, which in recent years is suffering a negative impact from human action, particularly population growth.

The family Cactaceae is recognized in Peru for presenting 43 genera and around 250 species $^{1}$. They are distributed in almost all ecosystems, from coastal deserts, western slopes, puna, inter-Andean valleys, successfully reaching the Amazon rainforest, mostly columnar cactus and 6 genera of endemic species ${ }^{2,3}$. It is native to the American continent, with the exception of one species, Rhipsalis that currently inhabits some tropical regions from Africa to Sri Lanka ${ }^{4}$.
They play an important role in the ecosystem, interacting and developing close relationships with other plant species called "mother plants" that provide the conditions of humidity, temperature for the establishment of new seedlings, and sometimes create the necessary conditions for the establishment of other cacti ${ }^{5}$. The stems, are the only source of fiber and water for wild animals in desert ecosystems, are a source of shelter, nesting for birds, visit of bats, as well as insects, for their flowers and fruits ${ }^{5,6}$. They present a series of particular biological and ecological characteristics that make them vulnerable to various natural and human disturbance factors ${ }^{7}$.

Cacti have long fascinated people and are now important in the ornamental plant trade, especially in Europe, Asia and North America, while they are still little appreciated in Latin American countries ${ }^{8}$. However, cactuses are one of the most vulnerable groups in the plant kingdom, where natural populations of many of the species have been affected by human development pressures, mainly due to the conversion of land for agricultural and/or livestock uses and the extraction activities of plants from their habitat, for sale as ornamental plants in national and international markets ${ }^{7}$. 
Little is known about the biology of many cactus species, it is essential to know some of their characteristics in order to carry out work that allows proposals for their conservation, particularly of endemic species. Those species that are restricted to a certain geographical area and are not found anywhere else in the world. Thus, these endemic cactuses are of vital importance because they are the treasure of a region or a country; they are very fragile and vulnerable to climate change and anthropogenic action?.

Peruvian endemism's are mostly associated with the Andes, have a restricted distribution and could be considered as the rarest organisms in the flora ${ }^{10}$. The departments with the greatest number of endemic taxa correspond to those with territory located on the Andean slopes ${ }^{11}$.

They are important because of their great biological value, contributing to the biodiversity of their ecosystem. These endemic species are very important in terms of conservation because any alteration in their habitat could be the cause of their disappearance or extinction ${ }^{10}$.

Therefore, endemism is an important tool for determining and examining the objectives and priorities of a strategy for the conservation of biological diversity. While the extreme richness of Peru's endemic flora is a source of pride for the country, at the same time it represents a very great challenge for the State and its allies in conservation ${ }^{11}$.

They possess particular biological and ecological characteristics that make them vulnerable to various perturbation factors, whether human or natural. Due to their slow growth and long life cycle, many of them are in some category of danger due to high levels of endemism ${ }^{10,12}$.
Diverse studies have contributed to the knowledge of cactus, so we have Nathaniel Lord Britton and Joseph Nelson Rose, initially worked in North America and later came to South America in 1914, working in central and southern Peru, central Bolivia, northern and central Chile, as well as other countries in South America, as a result they published his book in four volumes of great scientific importance "The Cactaceae. Descriptions and illustrations of plants of the cactus family" ${ }^{13}$. Later on, works such as Ecological and population characteristics of $\mathrm{Me}$ locactus nagyii mészáros (Cactaceae) in $\mathrm{Cuba}^{14}$, Diversity and distribution of Cactaceae in Guatema$\mathrm{la}^{4}$. In Peru there are works such as Catalogue of the flowering Plants and Gymnosperms of Peru ${ }^{1}$, Distribution and state of conservation of Haageocereus genus (Cactaceae family) in Lima department ${ }^{2}$, Red Book of the Endemic Plants of Peru ${ }^{15}$, Cactaceae. Endemics of Peru ${ }^{3}$, Categorization and Conservation of Peruvian Cactaceae ${ }^{16}$. All the Cactus of Pe$\mathrm{ru}^{17}$, Catalogue of the Cactaceae of the Department of Arequipa, Peru ${ }^{18}$.

Concerning the endemism for Peru, it is reported in terms of percentage considering the 10 departments in decreasing order Loreto (65\%), Puno (65\%), Cusco (52\%), Junin (48\%), Huanuco (46\%), Amazonas (46\%), San Martin (43\%), Piura (39\%), Ayacucho $(35 \%)$ and Pasco $(34 \%)^{11}$. Of which, the endemic genera richest in taxa belong to the family Cactaceae $^{11}$. With respect to Ayacucho, the highest percentage is related to cacti.

Similarly, in relation to conservation status, of 4197 categorized taxa (approximately 76\%) of the Peruvian endemic flora, the majority correspond to endangered species (EN) with $33 \%$, while those recognized as critically endangered (CR) reach $18 \%$. Twenty-four percent of the endemic flora was con- 
sidered to lack information for categorization and was therefore recognized as data deficient (DD) ${ }^{11}$. At a local level, "Native Cactaceae of Huamanga", carried out between altitudes of 2500-3800 masl, reporting 10 genera and 20 species in rocky and xerophytic formations and greater abundance in the spiny steppe life zone - Subtropical Lower Montane (ee-MBS) in the districts of Ayacucho, Pacaycasa and San Juan Bautista ${ }^{19}$.

Diversity, distribution and uses of cactus species in the province of Huamanga where they identified 16 species, 6 endemic Browningia hertlingiana, Echinopsis peruviana, Oroya peruviana, Corryocactus quadrangularis, Corryocactus ayacuchoensis and Oreocereus doelzianus According to the conservation status Corryocactus quadrangularis and Corryocactus ayacuchoensis are considered endangered (EN), Echinopsis peruviana is considered vulnerable (VU), while Browningia hertlingiana and Oroya peruviana are almost threatened (NT), the others are not evaluated (NE) ${ }^{9}$. Researchers continue to work to fill in part of the information gaps about cacti in this part of Peru. Therefore, this work was developed with the objective of diagnosing endemic species, their conservation status and population characteristics in the San Cristobal hill, Pacaycasa district, Huamanga province. Ayacucho.

\section{Material and methods}

Location. San Cristóbal Hill is located in the district of Pacaycasa, province of Huamanga, department of Ayacucho between $13^{\circ} 03^{\prime} 12^{\prime \prime}$ South and $74^{\circ} 12^{\prime} 48^{\prime \prime}$ West at 2535 meters above sea level ${ }^{20}$ and coordinates UTM $0580831 \mathrm{~m} \mathrm{E}$ and $8555278 \mathrm{~m} \mathrm{~N}$, in zone $18 \mathrm{~L}$. It has an area of 141.27 ha in an altitudi- nal range of 2453 to $2535 \mathrm{~m}$. It is located in an inter-Andean valley, settled on a steeply sloping terrain of alluvial formation and with a firm base of compact material (figure 1).

\section{Figure 1 Location map of San Cristobal Hill, Compañía community, Pacaycasa district. Ayacucho-Peru}

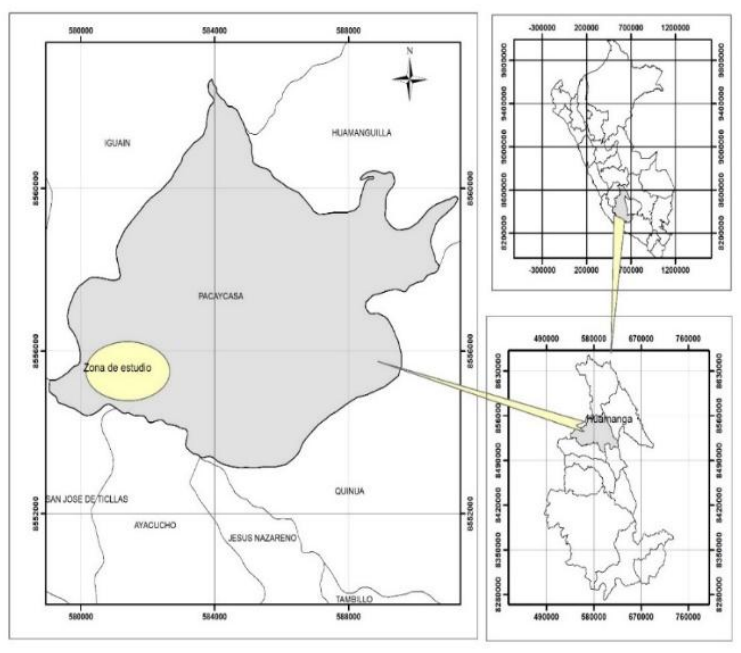

Figure 2 Physiography and vegetation of San Cristobal Hill, Compañía community, Pacaycasa district. Ayacucho-Peru

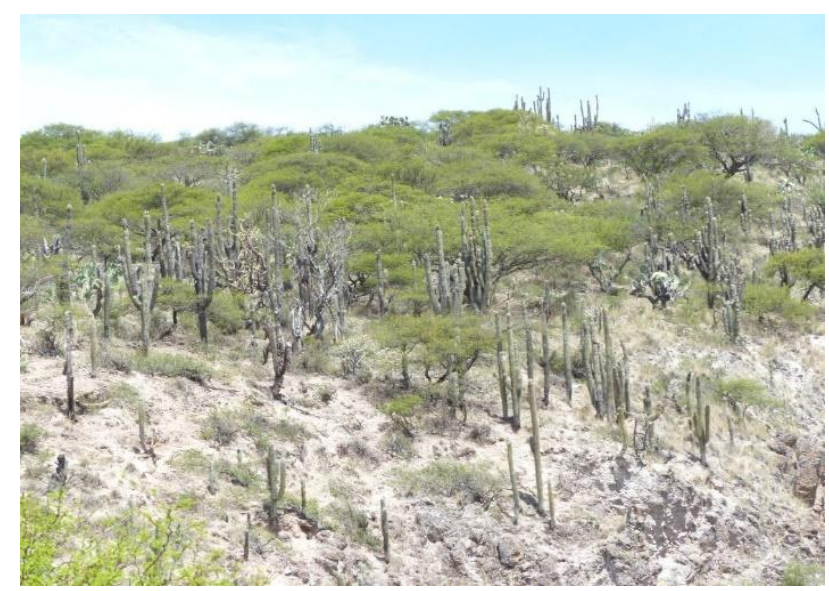

Its climate is temperate - warm, minimum temperature $12{ }^{\circ} \mathrm{C}$ in the months from May to July; maximum temperature up to $30{ }^{\circ} \mathrm{C}$ during the day in the months from August to October. Heavy rainfall occurs in the months of November to March, even 
April, being the dry months May to October, annual rainfall between 250 and $1000 \mathrm{~mm}^{20}$. According to the Ecological Map of Peru, it presents the following life zones: dry forest - Low Subtropical Mountain (bs-MBS) and thorny steppe - Low Subtropical Mountain (ee-MBS) ${ }^{21}$.

Methodology. Eight field trips were carried out during the months of January to September 2013, considering the rainy season and part of the dry season. The sampling was random-stratified, in order to obtain a representative sample of the population, considering sectors or strata according to the altitudinal levels ${ }^{22,23}$. To facilitate the study, San Cristobal Hill was zoned in three altitudinal $\operatorname{strata}^{24}$. ArcGIS software version 9.3 was used to stratify the study area and generate the corresponding map (table 1 and figure 3 ).

Figure 3 Mixed xerophytic community with presence of Acacia macracantha, Opuntia streptacantha, Browningia hertlingiana from San Cristobal hill, Compañía community, Pacaycasa district. Ayacucho-Peru

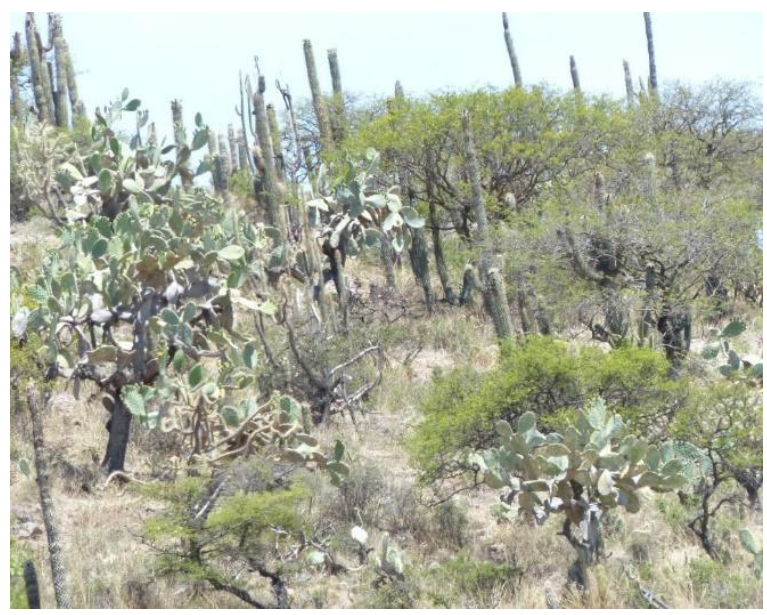

The plot method was used, with the area of each plot being $50 \mathrm{~m}$ x $50 \mathrm{~m}$ (0.25 ha). Twenty-four plots were chosen at random, 8 plots in each stratum. Each plot was georeferenced in UTM coordinates with the use of GPS (Global Positioning System), and sampling dates were recorded.

\section{Table 1 Stratification of San Cristobal Hill according} to altitude (masl)

\begin{tabular}{lcc}
\hline \multicolumn{1}{c}{ Name } & Symbology & Altitude range (masl) \\
\hline Low Stratum & EB & $<2500$ \\
Medium Stratum & EM & $2500-2600$ \\
High Stratum & EA & $>2600$ \\
\hline
\end{tabular}

To determine the number of sample units, a pilot sampling was carried out, using the following for$\operatorname{mula}^{24,22}$.

$$
n=\frac{t^{2} * C V^{2}}{E^{2}+\frac{t^{2} * C V^{2}}{N}}
$$

Where:

$\mathrm{n}=$ number of sample units

$\mathrm{E}=$ error with which you want to obtain the values of a certain parameter $\mathrm{t}=$ value obtained from the student's " $\mathrm{t}$ " tables, using $\mathrm{t}=0.05$

$\mathrm{N}=$ total number of sample units in the entire population

$\mathrm{CV}=$ coefficient of variation; to obtain this value it is necessary to make a pilot sampling

Figure 4 Map of the altitudinal strata of San Cristobal Hill, community of Compañía, district of Pacaycasa. Ayacucho 2013

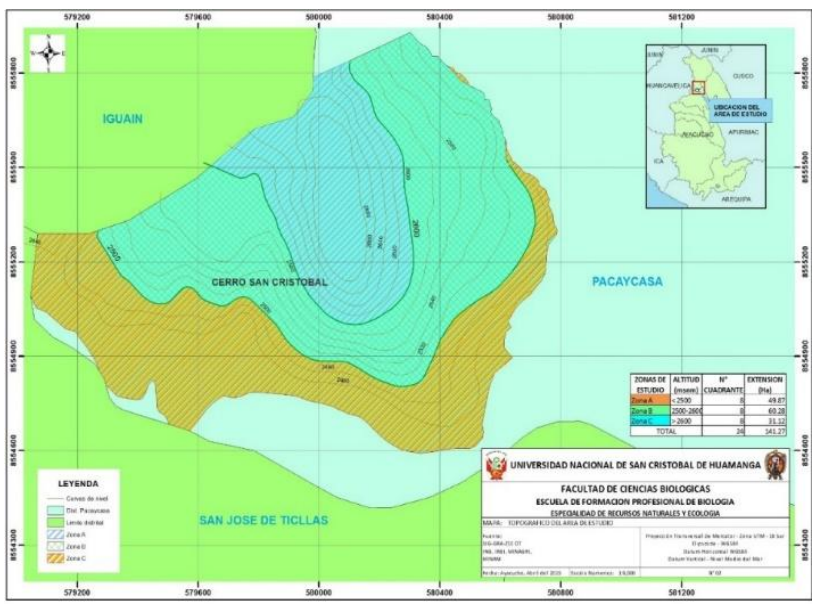

Identification of species. Once the sampling units were established, the endemic species were identified in each one of them with the support of a specialist and confirmed with taxonomic keys from specialized bibliography and the review of the red book of endemic plants of Peru ${ }^{11,3}$. All the botanical characteristics of taxonomic importance were regis- 
tered, such as floral characteristics, fruits, growth forms, number of ribs and everything related to globids and thorns. As well as field information.

Conservation status of species. For the state of conservation of species, we consulted the species protected by national legislation where they approve the categorization of threatened species of wild flora according to Supreme Decree No. 043-2006- $\mathrm{AG}^{25}$ and the species protected by international legislation according to the IUCN red list ${ }^{26}$

Population density. Once the endemic cactus was identified, each of the sampling units counted individuals of each species. The following formula was used for the calculation ${ }^{22}$ :

$$
\mathrm{D}=\frac{\text { Number of plants of a species }}{\text { Total area sampled }}
$$

Population structure. As for the density, in each of the sampling units the height of each individual of each species was measured, using a flexometer for small plants and a clinometer for taller plants. While the diameter with a Vernier ruler. If the plant had more than one branch from the base, all branches were recorded. Even though the cactuses do not have a defined crown, the cover was recorded to calculate the space they occupy in the ecosystem ${ }^{24}$.
Because there is no proposed and proven method to estimate the age of plant species, height measurements were grouped by size (height) categories to determine population structure.

Spatial distribution. The spatial distribution pattern of the species in the study area, we proceeded to map the individuals of each species using a GPS. The distance between individuals was also measured. It was located on a map considering the coordinate system for which the interpretation method of variance and mean was used ${ }^{27}$.

Table 2 Types of spatial distribution according to the relationship of variance and mean

\begin{tabular}{cc}
\hline Distribución & $\mathbf{S}^{2} / \overline{\mathrm{X}}$ \\
\hline Fortuita/azar & $\mathrm{S}^{2} / \overline{\mathrm{X}}=1$ \\
Uniforme & $\mathrm{S}^{2} / \overline{\mathrm{X}}<1$ \\
Amontonada & $\mathrm{S}^{2} / \overline{\mathrm{X}}>1$ \\
\hline
\end{tabular}

For the processing and analysis of results, computer tools such as Sofwtare R Version 3.0 and Microsoft Excel 2013 were used.

\section{Results}

Endemic species

Table 3 Registration of endemic species of the family Cactaceae in the San Cristobal hill, community of Compañía, district of Pacaycasa Ayacucho 2013

\begin{tabular}{llll}
\hline No. & Endemic species & Growth type & Growth form \\
\hline $\mathbf{1}$ & C. ayacuchoensis (Rauh \& Backeb) & Columnar & Arbustiva \\
$\mathbf{2}$ & C. quadrangularis (Rauh \& Backeb.) F.Ritter & Columnar & Arbustiva \\
$\mathbf{3}$ & B. hertlingiana (Rauh) Buxb. & Columnar & Arbóreo \\
$\mathbf{4}$ & E. peruviana (Britton \& Rose) Friedrich \& G.D. Rowley & Columnar & Arbóreo \\
$\mathbf{5}$ & O. doelzianus (Backeb.) Borg & Columnar & Arbustiva \\
\hline
\end{tabular}

\section{State of conservation}


Table 4 Categorization of endemic species of the Cactaceae family. Closed San Cristóbal, community of Compañía, district of Pacaycasa. Ayacucho 2013

\begin{tabular}{lcc}
\hline \multicolumn{1}{c}{ Species } & UICN & D.S.N 043 \\
\hline C. ayacuchoensis Rauh \& Backeb. & EN & \\
C. quadrangularis (Rauh \& Backeb.) F.Ritter & DD & EN \\
B. hertlingiana (Rauh) Buxb & LC & \\
E. peruviana (Britton \& Rose) Friedrich \& G.D. Rowley & LC & VU \\
O. doelzianus (Backeb.) Borg & LC & \\
\hline Endangered (EN), Data Deficient (DD), Least Concern (LC), Vulnerable (VU) & &
\end{tabular}

\section{Characterization of the species}

Peruvian Echinopsis (Britton \& Rose) Friedrich \& G.D. Rowley. Tree columnar cactus, columnar growth, sometimes arched, up to $5 \mathrm{~m}$ high, blue- green, 6 to $15 \mathrm{~cm}$ in diameter, 4 to 9 wide ribs, 10 unequal spines $4 \mathrm{~cm}$ long. White flowers, fragrant, 20 to $25 \mathrm{~cm}$ long. Fruit $5 \mathrm{~cm}$ long, green, rounded, dehiscent (figure 5).

Figure 5 Echinopsis peruviana. A. Stem, B. Stem cross section (9 ribs)

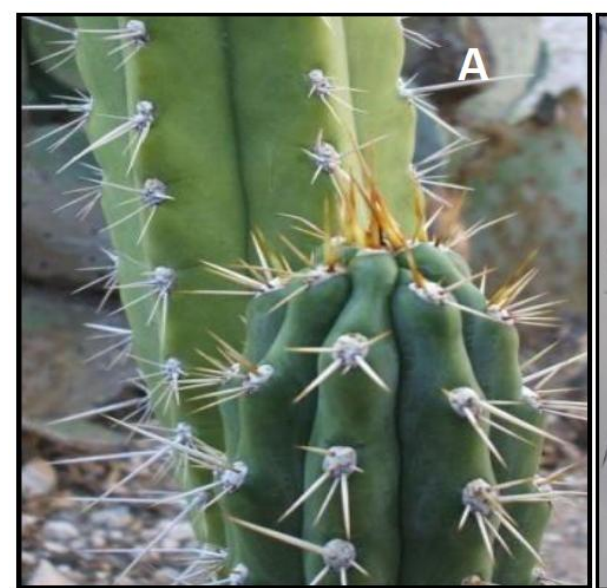

Corryocactus ayacuchoensis Rauh \& Backeb.. Columnar cactus 1 to $2 \mathrm{~m}$ high, 5.5 to $8 \mathrm{~cm}$ in diameter, with 3 to 10 basal branches. 5 to 7 ribs, yellowbrown or slightly whitish spines, radial in number from 8 to 12 and $2 \mathrm{~cm}$ long, central 3 to $4,3.5$ to 5 $\mathrm{cm}$ long. Weak red to slightly pink flowers, 4 to 5 $\mathrm{cm}$ long and $5 \mathrm{~cm}$ wide, apical growth. Fruit greenyellowish, 2.5 to $3.5 \mathrm{~cm}$ in size. Seeds black-brown (figure 6).

Corryocactus quadrangularis (Rauh \& Backeb.) F. Ritter. Columnar shrub cactus, branched from the

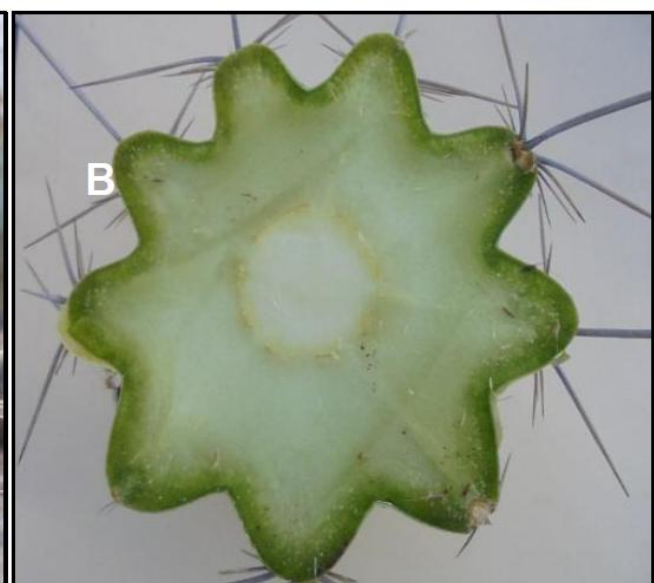

base, 1 to $2 \mathrm{~m}$ high, 4 to $5 \mathrm{~cm}$ in diameter, 4 to 5 deep ribs, brown spines 3 to 4 central 4 to $6 \mathrm{~cm}$ long, 4 to 8 radial 1 to $2 \mathrm{~cm}$ long. Intense and bright red flowers from 4 to $5 \mathrm{~cm}$ long. Redish-green fruit $3 \mathrm{~cm}$ in diameter (figure 7).

Oreocereus doelzianus (Backeb.) Borg

Columnar shrub cactus, quite branched from the base forming a conglomerate. Cylindrical stems, 60 to $80 \mathrm{~cm}$ high, 6 to $8 \mathrm{~cm}$ in diameter, 7 to 11 rounded ribs, white to dark brown spines, strong central spine $4 \mathrm{~cm}$ long, radial spines 10 to $163 \mathrm{~cm}$ long. 
Apex of flower stems with long white woolly hairs and white-brown bristles, up to $5 \mathrm{~cm}$ long. Intense red - carmine flowers 8 to $10 \mathrm{~cm}$ long, $3 \mathrm{~cm}$ in diameter (figure 8).

Figure 6 Corryocactus ayacuchoensis. A. Fruit, B. Flower, C. Cross section (6 ribs)

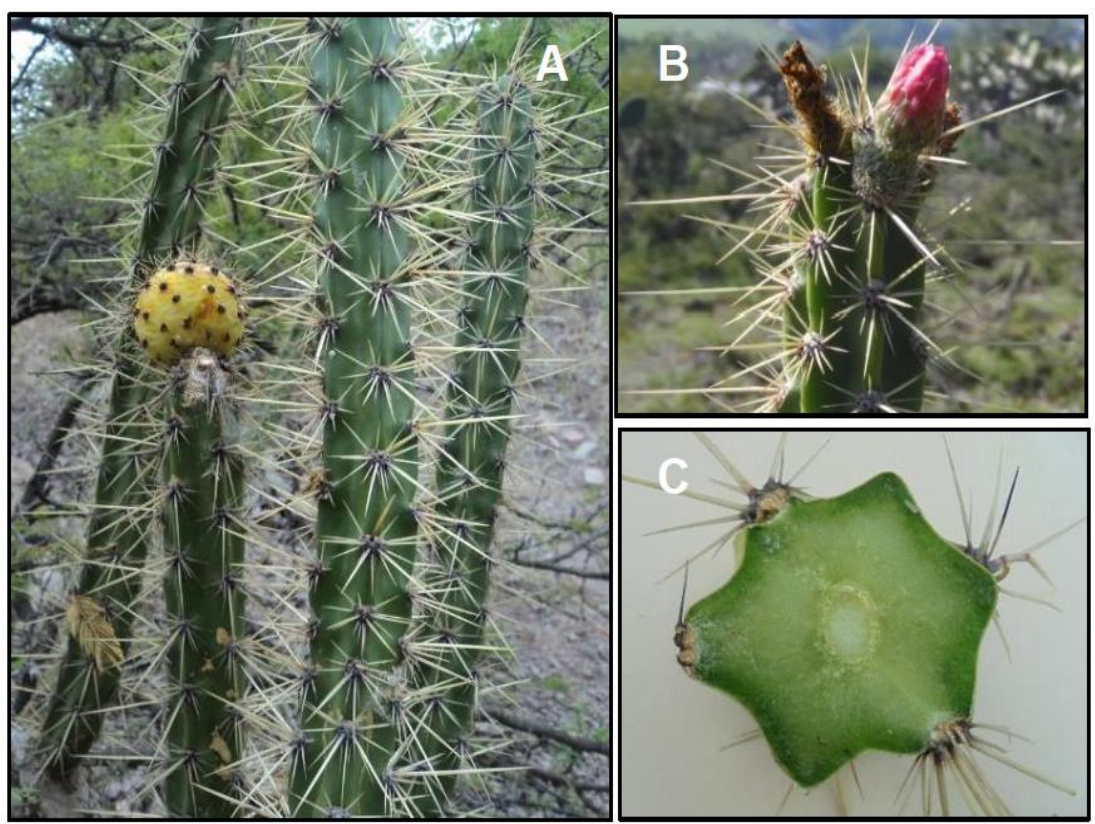

Figure 7 Corryocactus quadrangularis. A. Flower, B. Stem cross section (5 ribs)

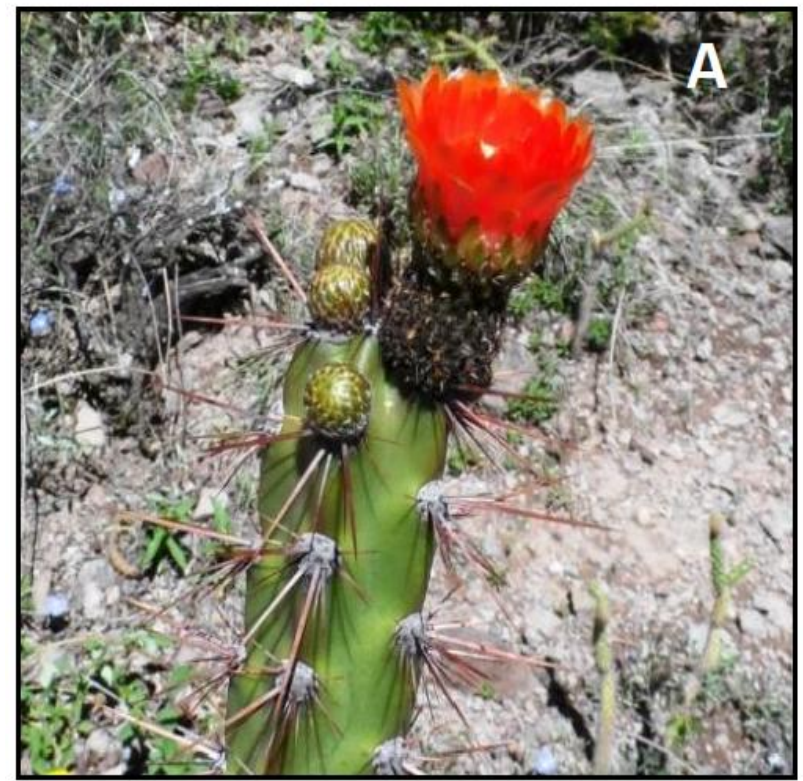

Browningia hertlingiana (Rauh) Buxb. Columnar arboreal cactus 5 to $7 \mathrm{~m}$ high. Strong woody main stem that branches one meter from the base, blue-

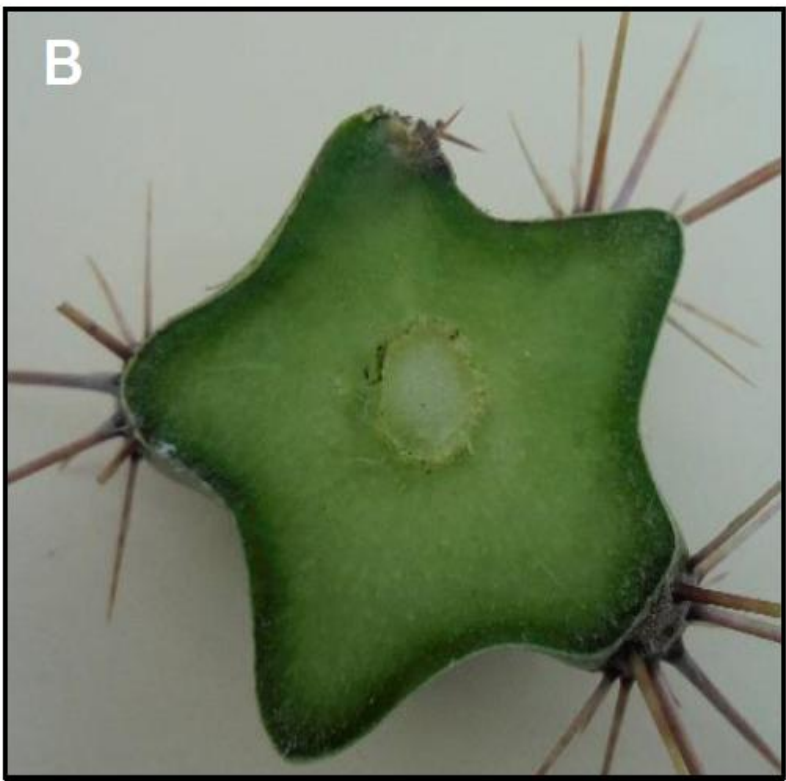

green in color, 10 to $20 \mathrm{~cm}$ in diameter, 13 to 18 tuberculated ribs, somewhat sunken areolas, strong central spines 1 to $3.8 \mathrm{~cm}$ long and the radial ones 6 
to 10 . Fruit of $5 \mathrm{~cm}$ in diameter in the form of onion, with floral and toothed scales. Small seeds of black color (figure 9).

\section{Discussion}

The results show that 05 species of cactus endemic to Peru were found on San Cristobal Hill: Cor- ryocactus ayacuchoensis Rauh \& Backeb., Corryocactus quadrangularis (Rauh \& Backeb.) F. Ritter, Browningia hertlingiana (Rauh) Buxb. Echinopsis peruviana (Britton \& Rose) Friedrich \& G.D. Rowley and Oreocereus doelzianus (Backeb.) Borg (table 3).

Figure 8 Oreocereus doelzianus. A. Flower, B. Fruit, C. Stem cross section (7 ribs)
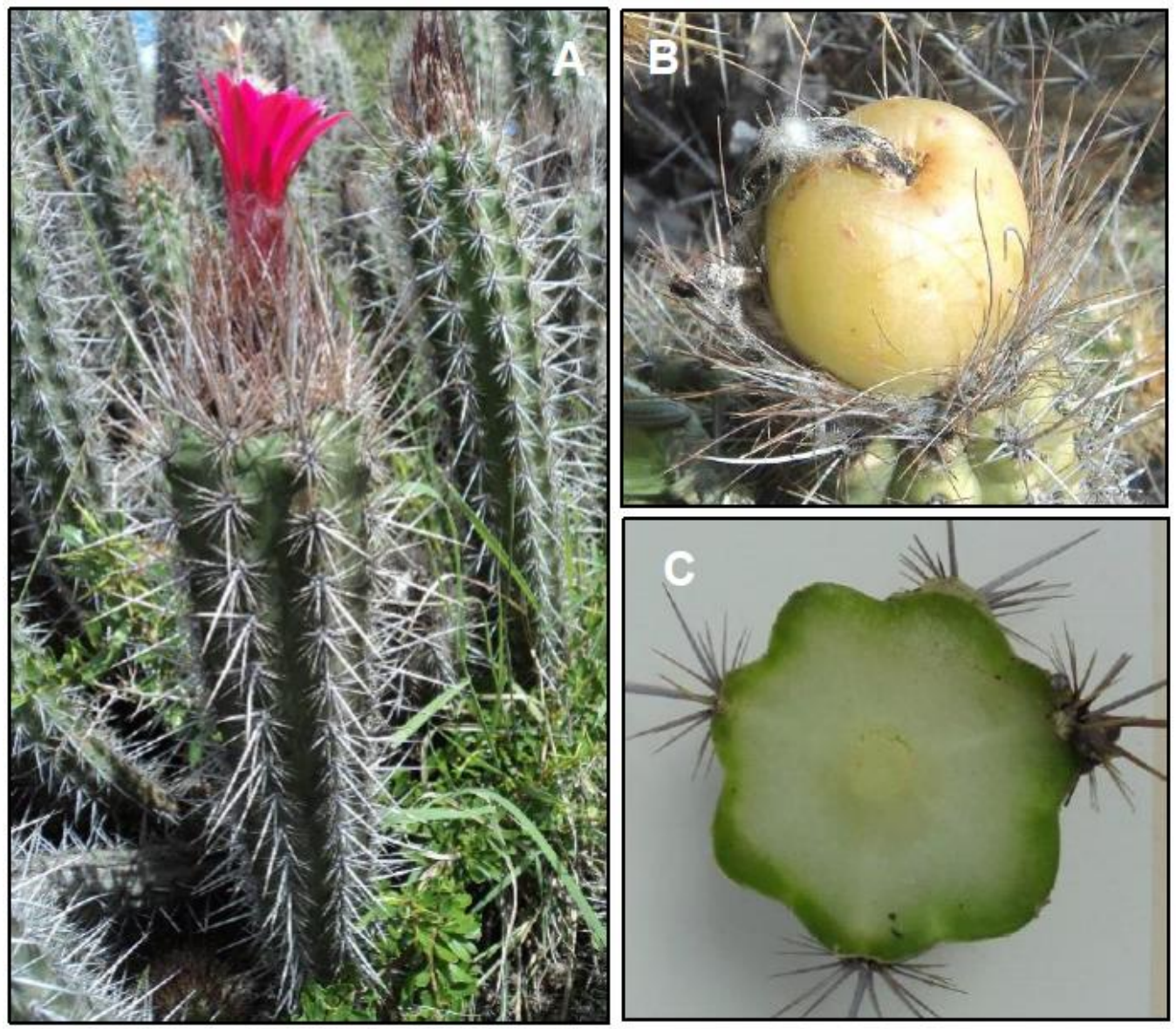

Table 5 Population density of endemic species of the Family Cactaceae in San Cristobal Hill, Compañía community, Pacaycasa district. Ayacucho 2013

\begin{tabular}{lcc}
\hline \multicolumn{1}{c}{ Species } & $\mathbf{N}^{\circ}$ plants & Plants/ha \\
\hline C. quadrangularis & 46 & 8 \\
E. peruviana & 51 & 9 \\
C. ayacuchoensis & 81 & 14 \\
O. doelzianus & 96 & 16 \\
B. hertlingiana & 801 & 134 \\
\hline \multicolumn{1}{c}{ Total } & $\mathbf{1 0 7 5}$ & \\
\hline
\end{tabular}


Figure 9 Browningia hertlingiana. A. Blue-green cactus, B. Flower, C. Fruit, D. Cross section of the stem (13 ribs)

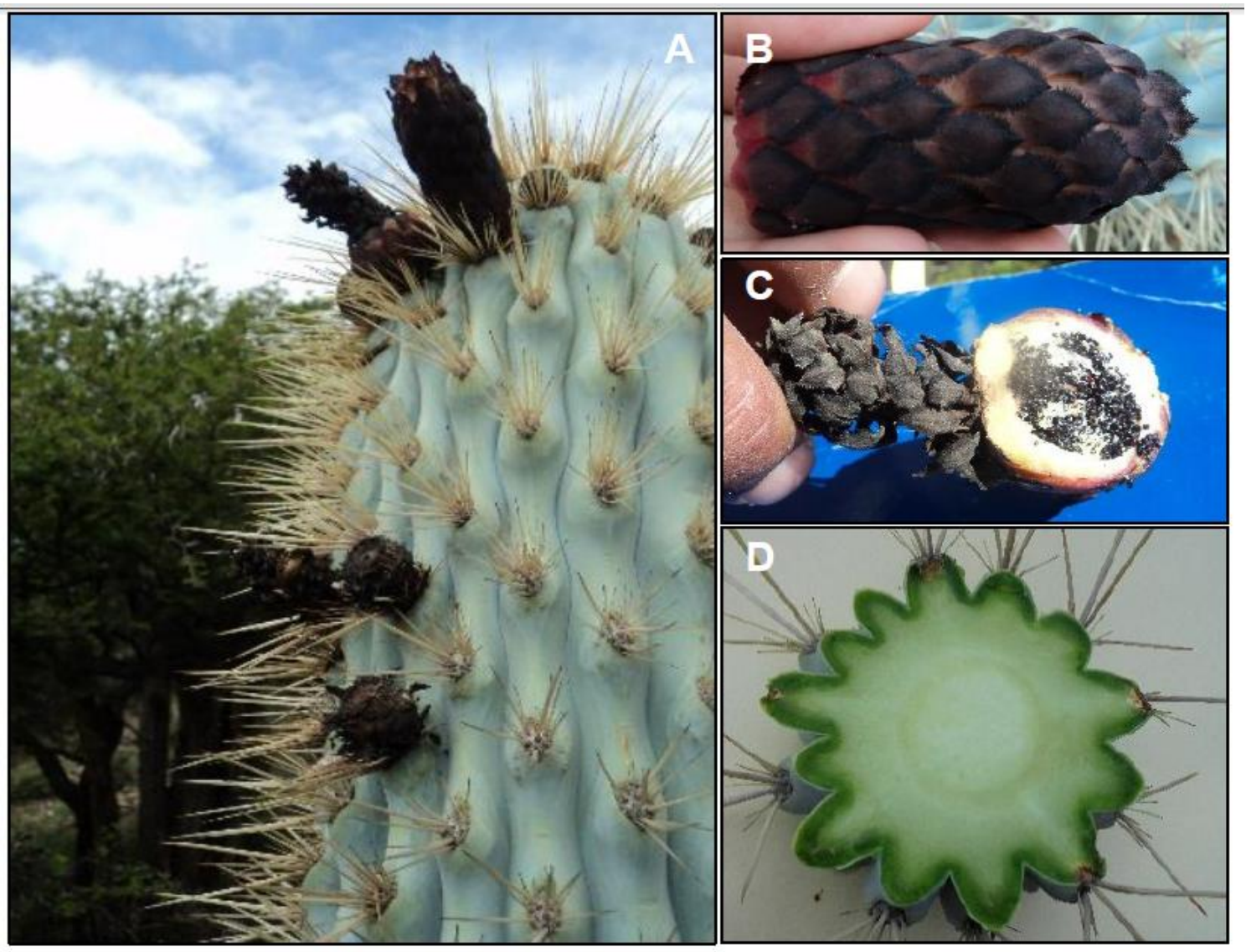

Table 6 Population density according to altitudinal strata of endemic species of the family Cactaceae in San Cristobal Hill, community of Compañía, district of Pacaycasa. Ayacucho 2013

\begin{tabular}{|c|c|c|c|}
\hline \multirow{2}{*}{ Species } & EB & EM & EA \\
\hline & Plants/ha & Plants/ha & Plants/ha \\
\hline C. quadrangularis & 9 & 7 & 8 \\
\hline E. peruviana & 10 & 8 & 8 \\
\hline C. ayacuchoensis & 8 & 9 & 24 \\
\hline O. doelzianus & 11 & 7 & 30 \\
\hline B. hertlingiana & 184 & 188 & 29 \\
\hline $\begin{array}{l}\text { EB } \\
\text { EM } \\
\text { EA }\end{array}$ & $\begin{array}{l}=\text { Low Stratum }(<250 \\
=\text { Medium Stratum }(25 \\
=\text { High Stratum }(>260\end{array}$ & $\begin{array}{l}\text { (nm) } \\
2600 \mathrm{msnm}) \\
\mathrm{snm})\end{array}$ & \\
\hline
\end{tabular}

Table 7 Spatial distribution of the populations of endemic species of the family Cactaceae in the San Cristobal hill, community of Compañía, district of Pacaycasa Ayacucho 2013

\begin{tabular}{lcc}
\hline \multicolumn{1}{c}{ Especies } & $\mathbf{S}^{2} / \overline{\mathrm{x}}$ & Distribución espacial \\
\hline C. ayacuchoensis & 8.29 & Amontonada \\
C. quadrangularis & 2,40 & Amontonada \\
E. peruviana & 1,24 & Amontonada \\
B. hertlingiana & 50,06 & Amontonada \\
O. doelzianus & 7,65 & Amontonada \\
\hline Randon $\mathrm{S}^{2} / \overline{\mathrm{X}}=1$. Uniform $\mathrm{S}^{2} / \overline{\mathrm{x}}<1$. Accumulate $\mathrm{S}^{2} / \overline{\mathrm{x}}>1$ &
\end{tabular}

Randon $\mathrm{S}^{2} / \overline{\mathrm{X}}=1$. Uniform $\mathrm{S}^{2} / \overline{\mathrm{X}}<1$. Accumulate $\mathrm{S}^{2} / \overline{\mathrm{X}}>1$ 
Figure 10 Population structure of Corryocactus ayacuchoensis, Corryocactus quadrangularis, Oreocereus doelzianus according to altitude range on San Cristobal hill, community of Compañía, district of Pacaycasa Ayacucho 2013

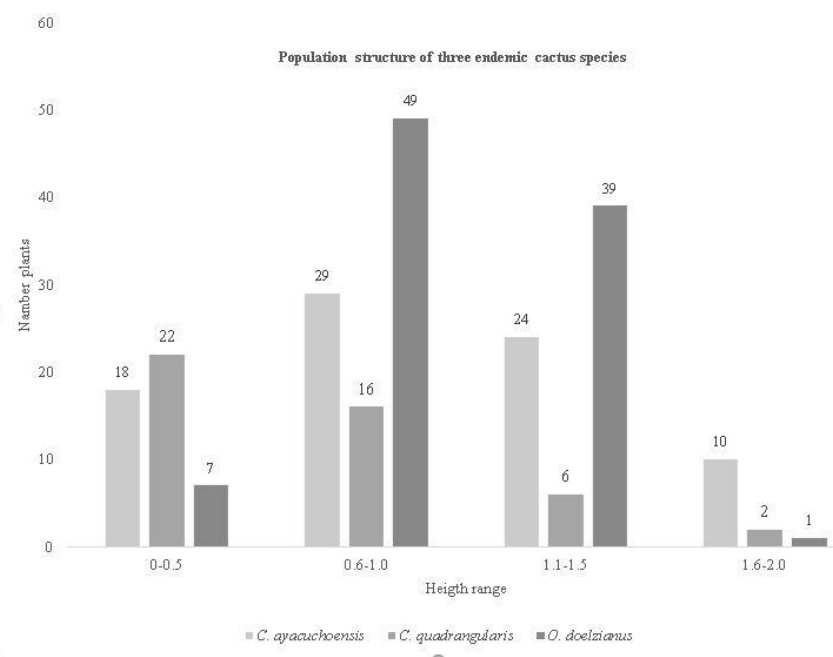

Figure 11 Population structure of Browningia hertlingiana according to altitude range in San Cristobal Hill, Compañía community, Pacaycasa district. Ayacucho 2013

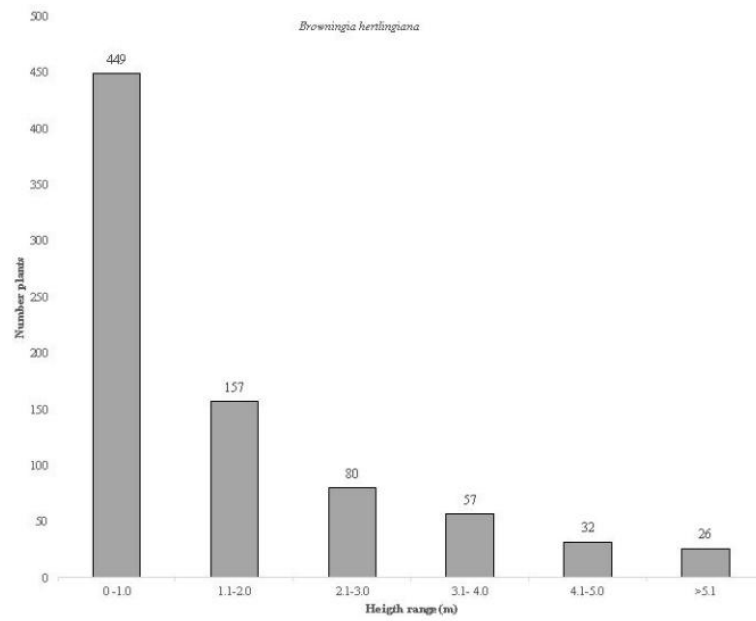

Figure 12 Population structure of Echinopsis peruviana according to altitude range on San Cristobal hill, community of Compañía, district of Pacaycasa. Ayacucho 2013

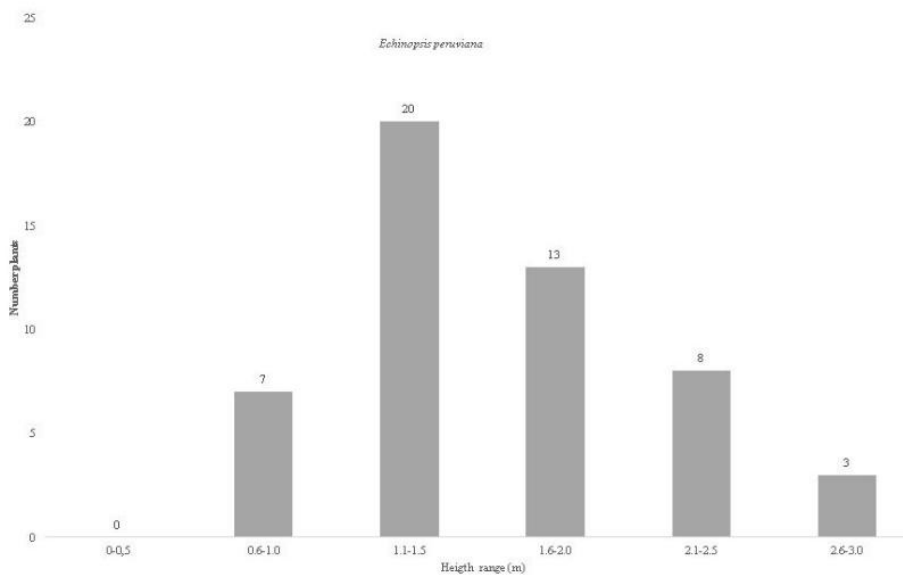


Valuable information that will contribute to the knowledge of this group of plants that due to their morpho-physiological adaptations play an important role in such a wild ecosystem, where survival is difficult. Aldazabal ${ }^{28}$ reported 11 species of the family Cactaceae for Cerro San Cristobal, according to the International Union for Conservation of $\mathrm{Na}$ ture $^{29}$, where it mentions the five species reported as part of this cactus community.

According to table 4 , the $\mathrm{IUCN}^{26}$ categorizes $C$. ayacuchoensis as endangered, because it is at extremely high risk of extinction in a wildlife state, $C$. quadrangularis, in Data Deficient, has inadequate information, to make an assessment of its extinction risk. B. hertlingiana, E. peruviana and O. doelzianus are in the Least Concern category because they are abundant and widely distributed ${ }^{29}$.

However, in the national legislation according to Supreme Decree $\mathrm{N}^{\circ}$ 043-2006-AG that Approves the Categorization of Threatened Species of Wild Flora $^{25}$, only 2 of the 5 endemic species are categorized, C. quadrangularis is Endangered and E. peruviana is Vulnerable, indicating that both are on the way to extinction. Therefore, it is very important that the categorization of these species is updated for the conservation and protection at a national and international level. This study will contribute to decision making by the corresponding authorities and prevent these species from becoming extinct. Information on the demographic aspects of the 5 endemic cactus species is important for conservation, maintaining the abundance and diversity of the species, will allow their survival ${ }^{2,17}$. For this reason, table 5 shows the population density and total number of plants registered in San Cristobal Hill, were 1075 endemic cactus plants, being the most abundant Browningia hertlingiana (801 plants), the second most abundant Oreocereus doelzianus (96 plants), followed by Corryocactus ayacuchoensis (81 plants), and in lesser quantity Echinopsis peru- viana and Corryocactus quadrangularis (51 and 46 plants respectively). In terms of density $B$. hertlingiana shows higher density 134 plants/ha compared to the other species such as Oreocereus doelzianus, Corryocactus ayacuchoensis, Echinopsis peruviana and Corryocactus quadrangularis present low densities, 16, 14, 9 and 8 plants/ha respectively. According to altitudinal strata in table 6 it is observed that $\mathrm{B}$. hertlingiana presents greater density in the three strata 184, 188 and 29 plants/ha. It reflects that this species is widely distributed and with higher density in all the study area, It is necessary to highlight the ecological role that this species plays, but it adorns the landscape with its spectacular growth form, branched and dominant columnar in a xerophytic ecosystem. While the other species present low densities in the three strata, an average of 7 to 30 plants/ha, despite the fact that the distribution of these species is wide, it is registered in the whole area, but the number of individuals of each species is very scarce. Moreover, the two species C. ауасиchoensis and C. quadrangularis, considered endangered species with very low numbers of individuals, are actually endangered. In fact, the species with the highest density and distribution throughout the area are those that have found the best environmental conditions. On the other hand, direct exposure or not of populations to sunlight does not seem to be a determining factor in the greater or lesser concentration of individuals, but this, combined with others, could influence population densities ${ }^{30,14}$.

Little is known about population studies of the cactus under study, however, in other ecosystems different from ours as carried out in Mexico by De Viana $^{31}$ of the genus Trichocereus, it presented a density of $43 \mathrm{ind} / \mathrm{ha} \pm 15$ in the area of Cardonal and $65 \mathrm{ind} / \mathrm{ha} \pm 38$ in Duendeyacu. The number of individuals within natural populations is very variable, since density is strongly influenced by environmental conditions, which can be originated by natural 
causes or by anthropogenic activities ${ }^{31}$, The same could be occurring in the cactus populations of this study that the low densities may be due to the negative impacts to which the population is subject, such as the constant trampling and browsing of cattle that come to graze in the area, which causes young individuals do not reach the stage of maturation, reducing reproduction and recruitment of seedlings. In the work carried out by Navarro - Carbajal \& Juarez Tentle $^{27}$, in Mexico, Mammillaria zephyranthoides presented an average density of 1.14 individuals $/ \mathrm{m} 2$, that is, $11400 \mathrm{ind} / \mathrm{ha}$. This value is very high compared to the density in the present study, these differences are due to different environmental characteristics, as well as the species and disturbances within the population ${ }^{27}$.

The cactus distribution pattern according to table 7 , the variance/average ratio was greater than one: 8.29 for C. ayacuchoensis, 2.40 C. quadrangularis, 1.24 E. peruviana, 50.06 B. hertlingiana and 7.65 for $O$. doelzianus, so the cactus is considered to have a stacked distribution. Similarly, studies conducted in Mexico ${ }^{8}$ on cactus diversity in preserved and disturbed sites, the results were the same, the ratio variance / average was greater than one: 44.47 in preserved sites and 49.39 in disturbed, indicating a stacked distribution. This type of distribution of individuals in space can occur due to: 1) local differences in habitat, 2) response to daily and seasonal atmospheric changes, or 3) as a result of regressive processes. In this way, the stacked distribution pattern may be due to the establishment of the cacti under the mother plants as they provide microclimatic conditions that can be exploited by them ${ }^{8}$. In relation to the population structure of the cactus: figure 10 it is observed that the three species $C$. ayacuchoensis, C. quadrangularis and $O$. doelzianus presented a greater number of plants in the height range of 0.6 to $1.5 \mathrm{~m}$ compared to young plants or recruits. This indicates to us that the popu- lation has some problem in its natural regeneration and if we project ourselves in the future it could have problems.

$B$. hertlingiana presents another particularity in its population structure because it was found in greater quantity, plants of lesser height: less than $1 \mathrm{~m}$ and 1.1 to $2.0 \mathrm{~m}$ with 450 and 160 individuals respectively and in less quantity plants greater than $2.1 \mathrm{~m}$ height. The presence of seedlings and young plants in greater quantity in this species reflects that there is natural regeneration in this population, however, the negative impact of the population in this ecosystem was observed (figure 11). E. peruviana presents a greater number of individuals in the range of 1.1 to $1.5 \mathrm{~m}$ and 1.6 to $2.0 \mathrm{~m}$ in height, with 20 and 13 plants respectively and a scarce number of plants of smaller and greater height (figure 12).

All information related to ecological, biological aspects of these threatened species will provide an overview of their current conservation status, such as the availability of sites for their survival, growth and recruitment. Valuable information for conducting more detailed ecological studies, or for making decisions related to these species. Such information can be used to conduct demographic studies or monitoring to quantify changes in populations over ti$\mathrm{me}^{32}$.

The low growth rates of many cacti, as well as their low levels of recruitment, mean that populations usually recover demographically extremely slowly after a disturbance. In addition, their particular geographic distribution patterns represent an enormous survival risk to any form of local disturbance ${ }^{7}$.

Therefore, when a population has a large number of young people, the population is growing, while if there are more adults than young people, the population is decreasing. Thus in B. hertlingiana the population is growing (because of its high proportion of young individuals) unlike the other species. This is because in the columns, fertility increases 
with size, reproductive structures develop mainly in the adult category, however the production of flower structures can start in individuals of smaller categories but in minimum proportion ${ }^{33}$.

Even if populations are in balance and growth, we must take into account that only if the same conditions persist will populations be maintained, but if they are altered they could decrease their growth and the persistence of the same could be at risk. Currently the habitats that these species occupy are threatened by human disturbance, land use change and fragmentation. Ostolaza-Nano ${ }^{16}$, in its work Categorization and conservation of Peruvian cactus, mentions that the conservation of cactus in general and its endemic species in Peru are still irrelevant, unnecessary and even impertinent, however, in other countries such as Mexico, the United States, Brazil or Chile, it is being given due importance ${ }^{16}$. Valencia-Diaz et $\mathrm{al}^{34}$ reported that in cactus populations deforestation has fragmented the habitat causing populations to become isolated and in turn separated from other populations of the same species. In the case of the habitat of Mammillaria eriacantha, a species endemic to Mexico, it has been fragmented as a result of the removal of rock to use the land for agricultural purposes, which caused the isolation of the populations of this cactus, making its dispersal mechanism as efficient as to avoid the crops that surround them and be able to colonize other sites. It may be that human settlements around a cactus population interrupt the dispersal of seeds and the cover of garbage prevents colonization, which could promote the local extinction of $M$. eriacantha in that fragment. The high degree of endemism of the cactus makes it one of the families most vulnerable to changes in their habitat. In addition, as slowgrowing individuals, the probability of recovery will also be slow, particularly if the adults who are the seed producers are removed ${ }^{34}$.
Natural habitats of cacti are heavily disturbed by urban expansion, environmental pollution, and increasing demand for crop and grazing areas for goats $^{2}$. Consequently, the categorization of plants, according to their threat of extinction, is of vital importance to carry out conservation plans. Such categorization is carried out by the $\mathrm{IUCN}^{29}$ using basically two criteria: the abundance of a taxon (number of individuals) and the total area of occupation of that taxon. The best strategy for the longterm conservation of biological diversity in these locations would be the conservation of natural populations and communities in their wild state, known as in situ conservation. However, because this option is often not viable, due to increasing human activity, it is likely that the only way to protect these species from extinction is through ex situ conservation strategies. In these cases, the Botanical Gardens, as centers of ex situ conservation, are in a unique position to contribute to conservation efforts because the living collections in these centers and their respective herbarium of dry plant collections represent the best source of information on plant distribution and habitat requirements ${ }^{2,12}$. Or the recent proposal, the creation of small municipal reserves in the habitats, which creates reserves in the same threatened locations, with the support of the community or groups interested in cacti and their conservation, to save these taxa without separating them from their natural environment ${ }^{17}$.

The study allowed us to know 5 species of endemic cacti Corryocactus ayacuchoensis Rauh \& Backeb., Corryocactus quadrangularis (Rauh \& Backeb.) F. Ritter, Browningia hertlingiana (Rauh) Buxb, Echinopsis penruviana (Britton \& Rose) Friedrich \& G.D. Rowley, Oreocereus doelzianus (Backeb.) Borg. Of which Browningia hertlingiana has the highest population density, while the others are very rare. Its distribution is piled up. Although there is natural regeneration. However, two endemic species 
typical of the zone, C. ayacuchoensis and C. quadrangularis, are in danger due to the negative impact generated by population growth in the study zone.

\section{Source of funding}

The research project has been self-financed with logistical support from the FOCAM project "Phanerogamic flora of the gas influence zone of CAMISEA and the implementation of the plant biodiversity database. Ayacucho-Peru" of the UNSCH.

\section{Interest conflicts}

The work was done on San Cristobal Hill, a community of company in the district of Pacaycasa, province of Huamanga. Ayacucho - Peru. The authors declare no conflict of interest.

\section{Acknowledgments}

To Mr. Reynán Cóndor Alarcón for his collaboration in the statistical analysis. To the students of the Vocational School of Biology Sthefany Navarro, Roxana Pariona, Ingrid Rodriguez, Yasmani Larota, Edgar Vilca and Mr. Abel Yulgo, Efraín Janampa, Walter Yance, Javier Portillo and Elver Coronado, for their support in the field work.

To the FOCAM Project "Phanerogamic flora of the gas influence zone of CAMISEA and the implementation of the database of the vegetal biodiversity. Ayacucho-Peru" of the National University of San Cristobal de Huamanga, for providing logistical support.

\section{Ethical aspects}

The research was carried out with the approval of jurors appointed by the Faculty of Biological Sci- ences of the National University of San Cristobal de Huamanga.

\section{Cited Literature}

1. Brako L, Zarucchi JL. Catalogue of the flowering Plants and Gymnosperms of Perú. Monog Syst Bot 1994;121(3):301. DOI: https://doi.org/10. 23 $\underline{07 / 2997188}$

2. Calderón Moya-Méndez N, Ceroni Stuva A, Ostolaza C. Distribución y estado de conservación del género Haageocereus (Familia Cactaceae) en el departamento de Lima. Ecol. Apl 2004;3(12):17-22. DOI: https://doi.org/10.21704/rea.v3i1 $\underline{-2.266}$

3. Arakaki M, Ostolaza C, Cáceres F, Roque J. Cactaceae Endémicas del Perú. Rev Peru Biol 2006; 13(2):193-219. DOI: https://doi.org/10.15381/rpb .$v 13 i 2.1821$

4. Arias S, Véliz Pérez ME. Diversidad y distribución de las Cactaceae en Guatemala. En: Cano E, editor. Biodiversidad de Guatemala [Internet]. Guatemala: Cactaceae; 2006. p. 2019-38. Recuperado a partir de: http://www.ibiologia.unam. $\mathrm{mx} / \mathrm{slccs} / \mathrm{www} / \mathrm{material}$ bib/A/Arias_y_Veliz_20 06_Cactaceae_Guatemala.pdf

5. Ceroni Stuva A, Castro Cepedo V, Teixeira Roth V, Redolfi Pivatto I. Neoraimondia arequipensis subsp. roseiflora (Werdermann \& Backeberg) Ostolaza (Cactaceae): eje de las interacciones en ecosistemas áridos. Ecol. Apl 2007;6(1-2):15568. DOI: https://doi.org/10.21704/rea.v6i1-2.352

6. Galán de Mera A, Vicente Orellana JA, Linares Perea E, Campos de la Cruz J, Trujillo Vera C, Villasante Benavides F. Patrones de distribución de las comunidades de cactáceas en las vertientes 
occidentales de los andes peruanos. Caldasia 2012;34(2):257-75.

7. Hernández HM, Godinez H. Contribución al conocimiento de las cactáceas mexicanas amenazadas. Acta Botánica Mex 1994;(26):33-52. DOI: https://doi.org/10.21829/abm26.1994.690

8. Arias L. Diversidad de cactáceas en sitios conservados y perturbados de sierra de Huautla [tesis licenciatura]. Morelos: Universidad Autónoma del Estado de Morelos; 2008.

9. De La Cruz J, Aucasime L. Diversidad, distribución y usos de las especies de cactáceas en la provincia de Huamanga. Informe de Investigación. Facultad de Ciencias Biológicas. Universidad Nacional de San Cristóbal de Huamanga. Ayacucho-Perú; 2012.

10. Young BE. Distribución de las especies endémicas en la vertiente oriental de los Andes en Perú y Bolivia [Internet]. Virginia: NatureServe; 2007 [citado 22-de octubre de 2019]. 92 p. Recuperado a partir de: http://armoniabolivia.org/wp-content/ uploads/2016/07/02 2007-Franke-etal NatureSer ve-Book.pdf

11.León B, Pitman N, Roque J. Introducción a las plantas endémicas del Perú. Rev Peru biol 2006; 13(2):9-22. DOI: https://doi.org/10.15381/rpb.v $13 \mathrm{i} 2.1782$

12.Ramos López AL. Estudio poblacional de Mammillaria dixanthocentron Backeb. Ex Mottram en el Valle de Cuicatlán, Oaxaca [tesis maestría]. [Oaxaca]: Instituto Politécnico Nacional; 2007 [citado 26 de octubre de 2019]. Recuperado a partir de: https://tesis.ipn.mx/jspui/handle/123456 789/88

13. Britton NL, Rose JN. The Cactaceae. Descriptions and illustrations of plants of the cactus family [Internet].Washington: The Carnegie Institu- tion of Washington; 1919 [citado 22 de octubre de 2019]. 320 p. Recuperado a partir de: http:// publicationsonline.carnegiescience.edu/publica tions online/cactaceae/Britton Rose Cacta ceae_1.pdf

14.Martínez Quesada E, Reyes Domínguez OJ, Viña Dávila N, Viña Dávila L, Pacheco O, Acosta Cantilla F. Características ecológicas y poblacionales de Melocactus nagyii mészáros (Cactaceae) en Cuba. Foresta Veracruzana 2005;7(1):25-30.

15.León B, Pitman N, Roque J, Ulloa C. Introducción a las plantas endémicas del Perú. Rev Peru Biol 2006;13(2):9S-22.

16.Ostolaza Nano C. Categorización y conservación de cactáceas peruanas. Zonas Áridas 2002;7(1): 194-205. DOI: https://doi.org/10.21704/za.v7i1.7 $\underline{25}$

17. Ostolaza C. Todos los cactus del Perú [Internet]. Lima: Ministerio del Ambiente; 2014 [citado 22 de octubre de 2019]. 541 p. Recuperado a partir de: http://www.minam.gob.pe/diversidadbio logica/wp-content/uploads/sites/21/2014/02/documen t.pdf

18.Pauca Tanco A, Quiposcoa Silvestre V. Catálogo de las cactáceas del departamento de Arequipa, Perú. Arnaldoa 2017;24(2):447-96. DOI: https:// doi.org/10.22497/arnaldoa.242.24204

19.Magallanes C. Cactáceas nativas de Huamanga. Informe de Investigación. Facultad de Ciencias Biológicas. Universidad Nacional de San Cristóbal de Huamanga. Ayacucho-Perú; 1999.

20.Municipalidad Distrital de Pacaycasa. Plan de desarrollo concertado 2012-2021 Distrito de Pacaycasa [Internet]. Ayacucho: Municipalidad de Pacaycasa; 2012 [citado 22 de octubre de 2019]. 124 p. Recuperado a partir de: https://es.scribd. 
com/document/286968064/Pdc-Pacaycasa-2012$\underline{2021}$

21.Estudio: Zonificación Ecológica Económica Ayacucho [Internet]. Sistema Nacional de Información Ambiental. 2013 [citado 5 de marzo de 2019]. Recuperado a partir de: https://sinia. minam.gob.pe/documentos/zonificacion-ecologicaeconomica-ayacucho

22.Mostacedo B, Fredericksen T. Manual de métodos básicos de muestreo y análisis en ecología vegetal [Internet]. Santa Cruz de la Sierra: Proyecto de Manejo Forestal Sostenible (BOLFOR)Bolivia; 2000 [citado 22 de octubre de 2019]. 92 p. Recuperado a partir de: http://www.bio-nica. info/biblioteca/mostacedo2000ecologiavege tal. pdf

23.Barrientos J. Estructura y composición florística del bosque de "chachacomo" en la comunidad de Intiwatana del distrito de Vischongo-Ayacucho. [tesis licenciatura]. [Ayacucho]: Universidad Nacional de San Cristóbal de Huamanga; 2007.

24.Loyola Gonzales R, Portuguez Yactayo H, Matos Delgado D, Araujo Flores S, Millán Salazar B, Arana Bustamante C, et al. Guía de inventario de la flora y vegetación [Internet]. Lima: Ministerio del Ambiente; 2015 [citado 22 de octubre de 2019]. 49 p. Recuperado a partir de: http://www. minam.gob.pe/patrimonio-natural/wp -content/up loads/sites/6/2013/10/GU\%C3\%83-A-DE-FLO RA-Y-VEGETACI\%C3\%83\%E2\% 80\%9CN. compressed.pdf

25.Servicio Nacional de Certificación Ambiental para las Inversiones Sostenibles. Aprueban Categorización de Especies Amenazadas de Flora Silvestre [Internet]. Perú: Presidencia de la República del Perú; 2006. [citado 20 de septiembre 2019]. Recuperado a partir de: https://www. se-
nace.gob.pe/wp-content/uploads/2016/10/NAT3-3-03-DS-043-2006-AG.pdf

26.International Union for Conservation of Nature and Natural Resources [Internet]. The IUCN Red List of Threatened Species; 2020 [citado 26 de mayo de 2020]. Recuperado a partir de: https:// www.iucnredlist.org/

27.Navarro Carbajal MC, Juárez Tentle MS. Evaluación de algunos parámetros demográficos de Mammillaria zephyranthoides en Cuautinchán, Puebla, México. Zonas Áridas 2006;10(1):74-83. DOI: https://doi.org/10.21704/za.v10i1.553

28.Aldazábal M. Flora fanerogámica del Cerro San Cristóbal, Distrito Pacaycasa, Provincia de Huamanga. [tesis licenciatura]. Ayacucho: Universidad Nacional de San Cristóbal de Huamanga; 2013.

29.Unión Internacional para la Conservación de la Naturaleza. Categorías y Criterios de la Lista Roja de la UICN [Internet]. Gland: UICN, Gland, Suiza; 2012 [citado 22 de octubre de 2019]. 42 p. Recuperado a partir de: https://portals.iucn.org/ library/sites/library/files/documents/RL-2001001-2nd-Es.pdf

30.Rivas Martínez S, Rivas Sáenz S, Penas A. Worldwide bioclimatic classification system. Global Geobotany 2011;11:1-634.

31.De Viana ML. Distribución espacial de Trichocereus pasacana (Cactaceae) en relación al espacio disponible y al banco de semillas. Rev Biol Trop 1996-7;45(1):95-103.

32.Alvarez R, Godínez Álvarez H, Guzmán U, Dávila P. Aspectos ecológicos de dos cactáceas mexicanas amenazadas: implicaciones para su conservación. Bol Soc Bot Méx 2004;(75):7-16. DOI: https://doi.org/10.17129/botsci.1690 
33. Martínez Peralta C, Mancilla R, Altamirano Vázquez HG, Aguilar Morales G. Características poblacionales de Pachycereus weberi y su relación con polinizadores en la comunidad de Dominguillo en el Valle de Tehuacán-Cuicatlán, PueblaOxaca. Cact Suc Mex 2010;55(3):85-95.
34. Valencia Díaz S, Flores Palacios A, Castillo Campos G. Tamaño poblacional y características del hábitat de Mammillaria eriacantha, una cactácea endémica del centro de Veracruz. Bot Sci 2012;90(2):195-202. DOI: https://doi.org/10. 171 29/botsci.484

Editor's Note:

Journal of the Selva Andina Biophere (JSAB) remains neutral with respect to jurisdictional claims published on maps and institutional affiliations. 